\title{
The Effect of Re-Planting Trees on Soil Microbial Communities in a Wildfire-Induced Subalpine Grassland
}

\author{
Ed-Haun Chang ${ }^{1, *}$, Guanglong Tian ${ }^{2}$ and Chih-Yu Chiu ${ }^{3, *}$ \\ 1 Mackay Junior College of Medicine, Nursing and Management, Beitou, Taipei 11260, Taiwan \\ 2 Environmental Monitoring and Research Division, Monitoring and Research Department, \\ Metropolitan Water Reclamation District of Greater Chicago, 6001 W. Pershing Road, Cicero, IL 60804, USA; \\ TianG@mwrd.org \\ 3 Biodiversity Research Center, Academia Sinica, Nankang, Taipei 11529, Taiwan \\ * Correspondence: edhaun@yahoo.com.tw (E.-H.C.); bochiu@sinica.edu.tw (C.-Y.C.); \\ Tel.: +886-912-933-878 (E.-H.C.); +886-2-2787-1180 (C.-Y.C.)
}

Received: 14 August 2017; Accepted: 3 October 2017; Published: 7 October 2017

\begin{abstract}
Wildfire often causes tremendous changes in ecosystems, particularly in subalpine and alpine areas, which are vulnerable due to severe climate conditions such as cold temperature and strong wind. This study aimed to clarify the effect of tree re-planting on ecosystem services such as the soil microbial community after several decades. We compared the re-planted forest and grassland with the mature forest as a reference in terms of soil microbial biomass $\mathrm{C}$ and $\mathrm{N}\left(\mathrm{C}_{\mathrm{mic}}\right.$ and $\mathrm{N}_{\text {mic }}$ ), enzyme activities, phospholipid fatty acids (PLFA) composition, and denaturing gradient gel electrophoresis (DGGE). The $\mathrm{C}_{\text {mic }}$ and $\mathrm{N}_{\text {mic }}$ did not differ among the grassland, re-planted forest and mature forest soil; however, ratios of $\mathrm{C}_{\mathrm{mic}} / \mathrm{C}_{\text {org }}$ and $\mathrm{N}_{\mathrm{mic}} / \mathrm{N}_{\text {tot }}$ decreased from the grassland to re-planted forest and mature forest soil. The total PLFAs and those attributed to bacteria and Gram-positive and Gram-negative bacteria did not differ between the re-planted forest and grassland soil. Principle component analysis of the PLFA content separated the grassland from re-planted forest and mature forest soil. Similarly, DGGE analysis revealed changes in both bacterial and fungal community structures with changes in vegetation. Our results suggest that the microbial community structure changes with the re-planting of trees after a fire event in this subalpine area. Recovery of the soil microbial community to the original state in a fire-damaged site in a subalpine area may require decades, even under a re-planted forest.
\end{abstract}

Keywords: wildfire; enzyme activities; microbial biomass; phospholipid fatty acid; reforestation; subalpine

\section{Introduction}

In forest ecosystems, fire alters the soil microbial community composition and activity in the form of direct heat-induced microbial mortality [1,2]. Furthermore, loss of forest by fire and grass invasion may alter nutrient cycling and quality of organic matter [3], which can indirectly affect the soil microbial community. Soil bacterial and fungal biomass is lower in fire-induced grassland areas than unaffected forest areas [4]. Post-fire tree replanting can accelerate the recovery of forest function in an ecosystem [5], thereby leading to greater recovery of the soil microbial community.

In Taiwan, grasslands are generally distributed above the tree line, at 3100 to $3400 \mathrm{~m}$ above sea level (asl). Approximately 50 years ago, a wildfire led to a vegetation shift from forest to grassland at Tatajia, the saddle (2600 to $2800 \mathrm{~m}$ asl) of Yushan, one of the highest mountains ( $3950 \mathrm{~m}$ ) in East Asia. 
This region provides a unique environment for observing long-term ecological changes in vegetation succession in a subalpine area.

Soil microorganisms are critical for ecosystem function and contribute substantially to organic matter decomposition and maintenance of soil structure [6,7]. Fungi and bacteria often occupy separate ecological niches in the soil environment and play critical roles in nutrient cycling $[8,9]$. Microbial biomass increases quickly in the early forest succession stage and then decreases and remains at a constant level with long-term forest restoration [10]. Hedo et al. [11] reported that post-fire silvicultural treatment did not have a direct effect on soil microbial properties and soil enzyme activities. However, little is known about the response of microbial communities to the succession of vegetation after fire [12]. A decade after a forest fire in a tropical rainforest, the dominant soil bacteria and actinobacteria did not differ between unburnt and burnt areas [13]. On the other hand, with the construction of $16 \mathrm{~S}$ rRNA gene clone libraries, the diversity of bacterial communities was significantly lower in planted or natural forest than in fire-induced grassland soil in subalpine area after 3 decades [14]. Soil microbial biomass, activity and microbial community may increase with vegetation succession.

Analysis of phospholipid fatty acids (PLFA) is useful for determining the active soil microbial community structure [15]. It provides quantitative data on microbial communities [16]. As another simple, rapid and molecular technique, denaturing gradient gel electrophoresis (DGGE) can provide information on dominant microbial species such as bacteria, fungi, and target groups by the use of different primers in the same soil DNA extract [17].

With the hypothesis that replanting of trees in a wildfire-induced grassland might enhance the recovery of microbial communities and function, we examined microbial activities, biomass and community structure in a subalpine forest ecosystem after a fire disturbance using PLFA and DGGE.

\section{Materials and Methods}

\subsection{Site and Soil Sampling}

This study was conducted at Tatajia $\left(23^{\circ} 28^{\prime} \mathrm{N}, 120^{\circ} 54^{\prime} \mathrm{E}\right)$ in central Taiwan, a subalpine area of Yushan (Mt. Jade). The site has an elevation 2600-2800 m, and mean annual precipitation of $4100 \mathrm{~mm}$ and mean annual temperature of $9.5^{\circ} \mathrm{C}$. The area is a long-term ecological study site of subalpine forest ecosystems in Taiwan. Soils are characterized as Humic Dystrudepts with low base saturation and strong acidity (pH 3.6-4.2) [18].

The study involved 3 vegetation types: grassland, re-planted forest, and natural forest. The study site was covered by natural hemlock and cypress forest before the wildfire. The grassland used as a control had formed from a wildfire event approximately 50 years ago in the forest area. The vegetation in the grassland included dwarf bamboo (Yushania niitakayamensis (Hayata) Keng f.) and alpine silver grass (Miscanthus transmorrisonensis Poaceae). The re-planted forest adjacent to the grassland plots was established by planting Pinus taiwanensis Hayata about 30 years ago. The Pinus plantation was weeded for three years in the early stage of establishment, after which no management was applied to the plantation. The non-disturbed natural forest used as a reference is dominated by Chinese hemlock (Tsuga chinensis (Franch.) Pritzel ex Diels.) with low density of Taiwan false cypress (Chamaecyparis formosensis Matsum.), spruce (Picea morrisonicola Hayata), and Armand's pine (Pinus armandi Franch.). Natural and re-planted forest plots were separated by $200 \mathrm{~m}$ and were about $1 \mathrm{~km}$ away from grassland plots.

Each plot was demarcated into five subplots $(50 \times 50 \mathrm{~m}$; replicates $)$ for sampling. In each subplot, three samples were collected and mixed as a composite sample. The soil samples were collected in January 2010 and stored in an ice box for immediate transport to the laboratory. After removing undecomposed litter on the surface, soil samples were collected at $0-10 \mathrm{~cm}$ depth, which include a thin $\mathrm{O}$ horizon (Oa) and A horizon, using a metal auger $(8 \mathrm{~cm}$ diam.). Visible detrital material, such as roots and litter, was hand-removed by sieving, and then the soil samples were ground to 
pass through a 2-mm sieve. Soil samples were stored at $4{ }^{\circ} \mathrm{C}$ in the dark before analysis within one month. Subsamples were frozen at $-20{ }^{\circ} \mathrm{C}$ immediately after sampling for analysis of PLFA. Biochemical analyses, including microbial biomass and enzymatic activities, were completed using fresh samples within 1 month after field sample collection. Another subsample was air-dried for soil chemical analysis.

\subsection{Biochemical Assay}

Organic C and total $\mathrm{N}$ in soil samples were determined using an NSC elemental analyzer (NA1500 Series 2, Fisons, Italy). Total $P$ was determined using the Bray-1 method (Olsen and Sommers 1982). Soil subsamples were weighed and oven-dried for $72 \mathrm{~h}$ at $105{ }^{\circ} \mathrm{C}$ to determine the moisture content. Soil $\mathrm{pH}$ values of air-dried samples were measured using a combination of glass electrodes (soil: water ratio 1:2.5) [19]. Soil microbial biomass was analyzed using the chloroform fumigation extraction method [20]. Total organic $C$ in the extracted solution was measured with a total organic C analyzer (Model 1010 O.I. Analytical, College Station, TX, USA) and converted to microbial biomass $C\left(\mathrm{C}_{\text {mic }}\right)$ assuming a conversion factor of 2.22 [21]. Microbial $\mathrm{N}\left(\mathrm{N}_{\mathrm{mic}}\right)$ was calculated from ninhydrin-reactive $\mathrm{N}$ released from the biomass and determined colorimetrically at $560 \mathrm{~nm}$ [22].

Urease activity (EC 3.5.1.5) was determined as described in Kandeler and Gerber [23]. The determination of phosphatase activity (EC 3.1.3.2) followed the method of Tabatabai and Bremner [24]. Cellulase activity (EC 3.2.1.4) and xylanase activity (EC 3.2.1.8) were determined by the method of Schinner and von Mersi [25].

Extraction and analysis of PLFA was as described in [26]. Lipids were extracted in a single-phase mixture of chloroform-methanol-citrate (1:2:0.8). Phospholipids were split into neutral and glycoland phospholipids using a solid-phase extraction column and eluted with chloroform, acetone and methanol. Phospholipids then underwent methylation to form fatty acid methyl esters (FAMEs). FAMEs were identified, and their content was quantified by capillary gas chromatography (GC) with a flame ionization detector (Thermo Finnigan Trace chromatograph) as described in [27]. Fatty acid nomenclature followed Frostegård et al. [26]. The fatty acids i15:0, a15:0, 15:0, i16:0, 16:1 $\omega 7 \mathrm{c}, 17: 0$, i17:0,

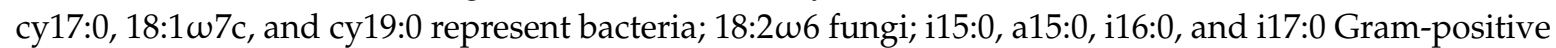

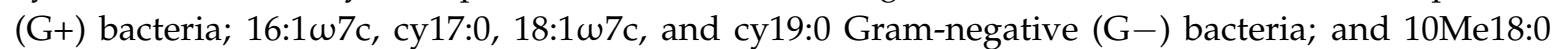
actinobacteria [28,29] (Zogg et al., 1997; Zelles 1999).

Soil DNA was extracted using the PowerSoil DNA isolation kit (MO BIO lab, Solana Beach, CA, USA). For soil bacteria, PCR conditions with primers F968-GC and R1401 [30] were as follows. The PCR mixtures $(50 \mu \mathrm{L})$ contained $20 \mu \mathrm{L}$ 2X Quick Taq HS DyeMix (Toyobo, Osaka, Japan), 10 pmol each primer, and $1 \mu \mathrm{L}$ template DNA and deionized water to bring the final volume to $50 \mu \mathrm{L}$. The PCR program was $2 \mathrm{~min} 94^{\circ} \mathrm{C}$, followed by 34 cycles of $94^{\circ} \mathrm{C}$ for 30 seconds, $61^{\circ} \mathrm{C}$ for 30 seconds and $68^{\circ} \mathrm{C}$ for $1 \mathrm{~min}$. For soil fungi, PCR conditions with primer NS1 and GC fungi [31] were as follows. The PCR mixtures $(50 \mu \mathrm{L})$ contained $20 \mu \mathrm{L} 2$ X Quick Taq HS DyeMix (Toyobo), 10 pmol each primer, and $1 \mu \mathrm{L}$ template DNA and deionized water to bring the final volume to $50 \mu \mathrm{L}$. The PCR program was 2 min $94{ }^{\circ} \mathrm{C}$, followed by 32 cycles of $94{ }^{\circ} \mathrm{C}$ for 30 seconds, $52{ }^{\circ} \mathrm{C}$ for 30 seconds and $68^{\circ} \mathrm{C}$ for $1 \mathrm{~min}$.

The PCR products were analyzed using DGGE as described [32]. The DGGE gel comprised 6\% polyacrylamide gel and 50\% to $70 \%$ denaturants for bacterial analysis and $7 \%$ polyacrylamide and $20 \%$ to $45 \%$ denaturants for fungal analysis. The electrophoresis was performed for $18 \mathrm{~h}$ at $50 \mathrm{~V}$ in $1 \times$ TAE buffer at a constant temperature of $58{ }^{\circ} \mathrm{C}$ for bacteria and $60{ }^{\circ} \mathrm{C}$ for fungi with a Dcode Universal Detection system (Bio-Rad Laboratories, Hercules, CA, USA). The gel was stained with Gelstar ( $20 \mu \mathrm{L}$ of Gelstar in $200 \mathrm{~mL}$ of $1 \times$ TAE buffer) for $30 \mathrm{~min}$, and then DGGE band profiles were visualized under UV light. Digital image capturing involved the use of a Gel Doc XR gel imaging system (Bio-Rad). The obtained DGGE fingerprints were analyzed for similarities between microbial communities by the Dice similarity index based on the unweighted pair group method with arithmetic averages (UPGAMA) with Quantity One 4.5.1 (Bio-Rad, Hercules, CA, USA). 


\subsection{Statistical Analysis}

Data from biological and chemical analyses were converted based on the oven-dried mass. Statistical analysis involved the use of Student's $t$-test to evaluate significance of difference between the means of the three vegetation systems. A normality test (Shapiro-Wilk test) for all variables was performed before the test, and non-normal distributed data were transformed logarithmically. Principal component analysis (PCA) was used to test biochemical properties and relative concentrations (mole \%) of individual fatty acids; relationships between vegetation types and individual PLFA were estimated using 2-D PC plots. Correlation between microbial parameters and soil properties involved Pearson's correlation coefficient. Statistical analyses involved SPSS v12.0 (SPSS Inc., Chicago, IL, USA). $P<0.05$ was considered statistically significant.

\section{Results}

\subsection{Soil Properties and Microbial Biomass}

Soil $\mathrm{pH}$ in the re-planted forest and grassland was similar and higher than in the mature forest (Table 1). Soil organic $\mathrm{C}$ and total $\mathrm{N}$ were higher in the mature than re-planted forest and grassland soil, with no significant difference between the re-planted forest and grassland soil. Soil total phosphorus did not show any significant difference among the three types of vegetation, although it was higher in the mature forest soil than in the re-planted forest and grassland soil. Soil microbial biomass $\mathrm{C}_{\text {mic }}$ and $\mathrm{N}_{\text {mic }}$ did not significantly differ among the three types of vegetation; however, the ratios of soil $\mathrm{C}_{\text {mic }} / \mathrm{C}_{\text {org }}$ and $\mathrm{N}_{\text {mic }} / \mathrm{N}_{\text {tot }}$ decreased from the grassland to the re-planted forest and mature forest.

Table 1. Soil chemical properties and microbial biomass characteristics in the three vegetation zones.

\begin{tabular}{|c|c|c|c|c|c|c|c|c|}
\hline Vegetation & $\mathrm{pH}$ & $\begin{array}{l}\text { Organic C } \\
\left(\mathrm{g} \mathrm{kg}^{-1}\right)\end{array}$ & $\begin{array}{c}\text { Total N } \\
\left(\mathrm{g} \mathrm{kg}^{-1}\right)\end{array}$ & $\begin{array}{c}\text { Total } P \\
\left(\mathrm{mg} \mathrm{kg}^{-1}\right)\end{array}$ & $\begin{array}{c}\mathrm{C}_{\text {mic }} \\
\left(\mathrm{mg} \mathrm{kg}^{-1}\right)\end{array}$ & $\begin{array}{c}\mathrm{N}_{\text {mic }} \\
\left(\mathrm{mg} \mathrm{kg}^{-1}\right)\end{array}$ & $\underset{(\%)}{C_{\text {mic }} / C_{\text {org }}}$ & $\underset{(\%)}{N_{\text {mic }} / N_{\text {tot }}}$ \\
\hline Grassland & $4.14 \mathrm{a}$ & $106 \mathrm{c}$ & $7.93 c$ & $606 a$ & $5505 a$ & $587 \mathrm{a}$ & $5.19 \mathrm{a}$ & $7.43 \mathrm{a}$ \\
\hline Mature forest & $3.56 \mathrm{~b}$ & $472 \mathrm{a}$ & $25.0 \mathrm{a}$ & $650 a$ & $6165 \mathrm{a}$ & $648 \mathrm{a}$ & $1.30 \mathrm{c}$ & $2.88 \mathrm{c}$ \\
\hline
\end{tabular}

$\mathrm{C}_{\text {mic }}$ : microbial biomass $\mathrm{C} ; \mathrm{N}_{\text {mic }}$ : microbial biomass $N$. In each column, different letters after the values indicate significant differences between treatments (Student's $t$-test, $p<0.05$ ).

\subsection{Soil Enzyme Activities}

Cellulase, xylanase and phosphatase activities were significantly higher in the mature forest soil than other soils, with no significant difference between the re-planted forest and grassland soil (Table 2). Urease activity was lowest in the re-planted forest soil, intermediate in the mature forest soil, and highest in the grassland soil $(p<0.05)$.

Table 2. Soil enzymatic activities in the three types of vegetation.

\begin{tabular}{|c|c|c|c|c|}
\hline Vegetation & $\begin{array}{l}\text { Cellulase (mg } \\
\left.\text { Glucose } \mathrm{g}^{-1} \mathrm{~d}^{-1}\right)\end{array}$ & $\begin{array}{c}\text { Xylanase }(\mathbf{m g} \\
\left.\text { Glucose } \mathrm{g}^{-1} \mathrm{~d}^{-1}\right)\end{array}$ & $\begin{array}{c}\text { Urease (mmole } \\
\mathrm{NH}_{4}^{+}-\mathrm{N} \mathrm{g} \mathrm{g}^{-1} \mathrm{~h}^{-1} \text { ) }\end{array}$ & $\begin{array}{l}\text { Acid Phosphatase }(\mu \mathrm{g} \\
\left.\text { Nitrophenol } \mathrm{g}^{-1} \mathrm{~h}^{-1}\right)\end{array}$ \\
\hline Grassland & $2.786 \mathrm{~b}$ & $5.252 \mathrm{~b}$ & $77.89 \mathrm{a}$ & $1919 \mathrm{~b}$ \\
\hline Re-planted forest & $0.867 \mathrm{c}$ & $5.167 \mathrm{~b}$ & $17.52 \mathrm{c}$ & $2189 \mathrm{~b}$ \\
\hline Mature forest & $5.608 \mathrm{a}$ & $10.98 \mathrm{a}$ & $41.90 \mathrm{~b}$ & $2897 \mathrm{a}$ \\
\hline
\end{tabular}

In each column, different letters after the values indicate significant difference between treatments. (Student's $t$-test, $p<0.05)$.

\subsection{PLFA Biomarkers}

The planting of trees in the grassland affected PLFA biomarkers (Table 3). The total PLFA content was higher in the re-planted forest than the grassland soil, though it was still lower than the mature forest. The levels of both fungal and arbuscular mycorrhizal fungal PLFA biomarkers were higher in 
the re-planted forest than the grassland soil. Bacterial biomass did not differ between the re-planted forest and grassland soil, nor did the PLFA levels of biomarkers for actinobacteria. The ratios of $\mathrm{G}+/ \mathrm{G}-$ and fungi/bacteria were higher but not significantly so in the re-planted forest compared with the grassland soil. Although the planting of trees increased the total PLFA and biomarker levels for fungi and arbuscular mycorrhizal fungi compared to the grassland, the levels of these microbial groups were still lower than those in the mature forest.

Table 3. Content of phospholipid acid biomarkers of the total microbial community and individual groups in soils under three types of vegetation.

\begin{tabular}{|c|c|c|c|c|c|c|c|c|c|}
\hline Vegetation & $\begin{array}{c}\text { Total PLFA } \\
\text { (nmol } \mathrm{g}^{-1} \text { soil) }\end{array}$ & Bacteria & Fungi & $\begin{array}{l}\text { VAM } \\
\text { Fungi }\end{array}$ & Actinobacteria & $\begin{array}{c}\mathrm{G}+ \\
\text { Bacteria }\end{array}$ & $\begin{array}{c}\mathrm{G}- \\
\text { Bacteria }\end{array}$ & $\mathrm{G}+/ \mathrm{G}-$ & $\begin{array}{c}\text { Fungi/ } \\
\text { Bacteria }\end{array}$ \\
\hline Grassland & $389 c$ & $202 b$ & $18.3 \mathrm{~b}$ & $14.7 \mathrm{c}$ & $31.6 \mathrm{~b}$ & $43.7 \mathrm{~b}$ & $91.1 \mathrm{~b}$ & $0.461 \mathrm{c}$ & $0.091 \mathrm{~b}$ \\
\hline Re-planted forest & $508 \mathrm{~b}$ & $223 b$ & $37.4 \mathrm{a}$ & $18.6 \mathrm{~b}$ & $37.4 \mathrm{~b}$ & $51.7 \mathrm{~b}$ & $94.8 \mathrm{~b}$ & $0.568 \mathrm{~b}$ & $0.168 \mathrm{a}$ \\
\hline Mature forest & $789 a$ & $371 \mathrm{a}$ & $52.3 \mathrm{a}$ & $22.5 \mathrm{a}$ & $53.7 \mathrm{a}$ & $99.2 \mathrm{a}$ & $131 \mathrm{a}$ & $0.755 \mathrm{a}$ & $0.187 \mathrm{a}$ \\
\hline
\end{tabular}

PLFA: phospholipid fatty acids; VAM, vesicular arbuscular mycorrhizal. In each column, different letters after the values indicate significant difference between treatments. (Student's $t$-test, $p<0.05$ ).

\subsection{Principal Component Analysis}

The first two PCA components explained $71.5 \%$ of the variability in the soil biochemical parameters. The first factor (PC axis 1), which explained $53.6 \%$ of the variance, was mainly positively associated with soil organic $\mathrm{C}$, total $\mathrm{N}$ and enzymatic activities and negatively associated with soil $\mathrm{pH}, \mathrm{C}_{\text {mic }} / \mathrm{C}_{\text {org }}$ and $\mathrm{N}_{\text {mic }} / \mathrm{N}_{\text {tot }}$ (Figure 1). The second factor (PC axis 2), which explained $19.7 \%$ of the variance, was associated with microbial biomass. The soil biochemical PCA plot (Figure 1a) separated the mature forest from the planted forest and grassland.
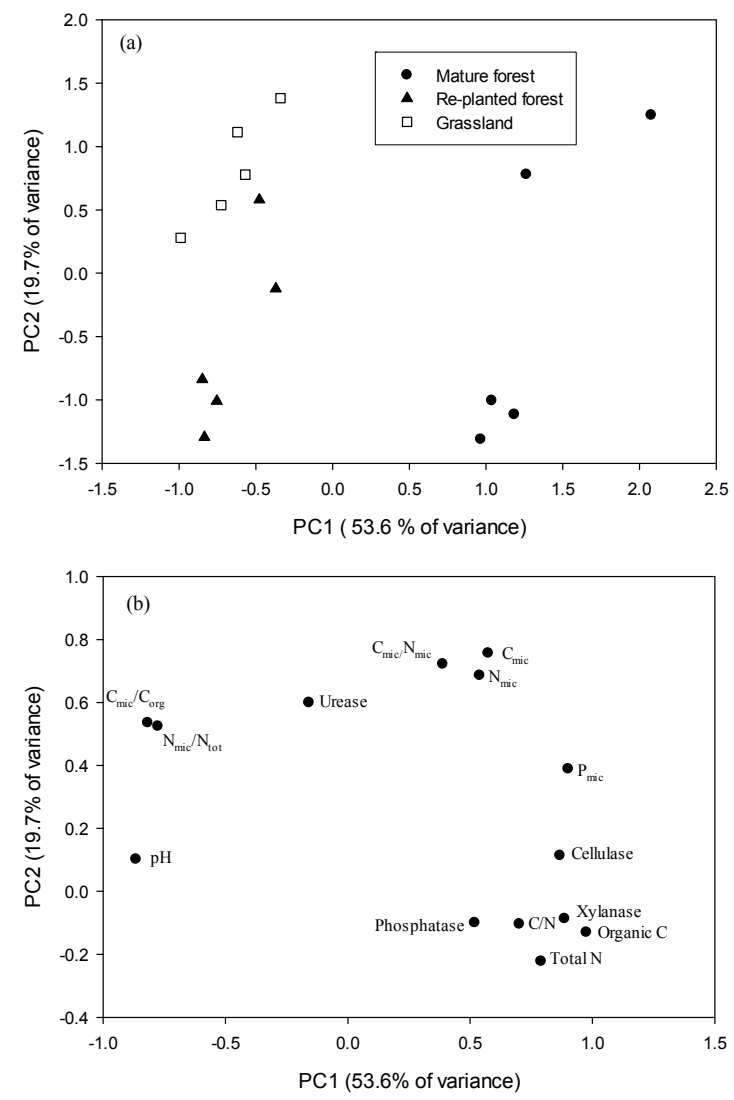

Figure 1. Plots of (a) the first 2 principal components (PCs) and (b) corresponding loading values in principal component analysis of the chemical and biochemical properties in the three types of vegetation. 
Soil microbial communities, as analyzed by the PCA of the PLFA levels, significantly differed among the three types of vegetation and could be divided into three clusters: mature forest, re-planted forest and grassland. The first and second principal components (PC1, PC2) accounted for $70 \%$ of the PLFA variability (Figure 2). The PC1 differentiated the mature forest from the other vegetation, and PC2 differentiated the grassland from the re-planted forest. High positive loadings for G+ bacteria (i15:0, a15:0, i16:0, 10Me16:0 and 10Me17:0), high negative loadings for G- bacteria (cy17:0 and $18: 1 \omega 7 \mathrm{c})$, and positive loading for fungi $(18: 2 \omega 6 \mathrm{c})$ contributed to the separation of the mature forest from other types of vegetation along the $\mathrm{PC} 1$ axis.
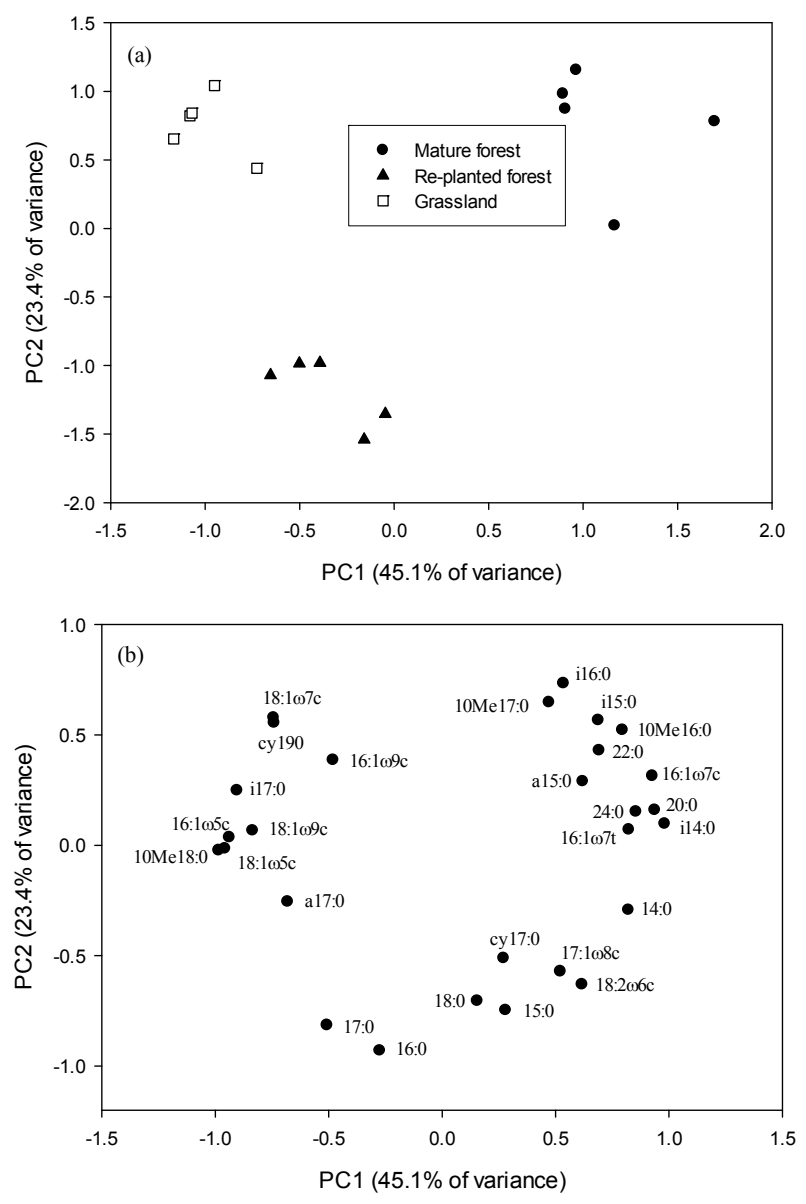

Figure 2. Plots of (a) the first 2 principal components (PCs) and (b) corresponding loading values in the principal component analysis of the mole \% of microbial phospholipid fatty acids in three types of vegetation.

\subsection{DGGE Analysis}

Dendrograms of genetic similarity obtained by DGGE of bacterial communities in the soil samples clustered differently for different types of vegetation (Figure 3). For soil bacterial communities, the re-planted forest and grassland were in one group, whereas in the other group was the mature forest.

Similarly, cluster analysis of fungal communities showed two main clusters for the three types of vegetation (Figure 4). Re-planted forest and grassland soil clustered together, being separate from the mature forest soil. 


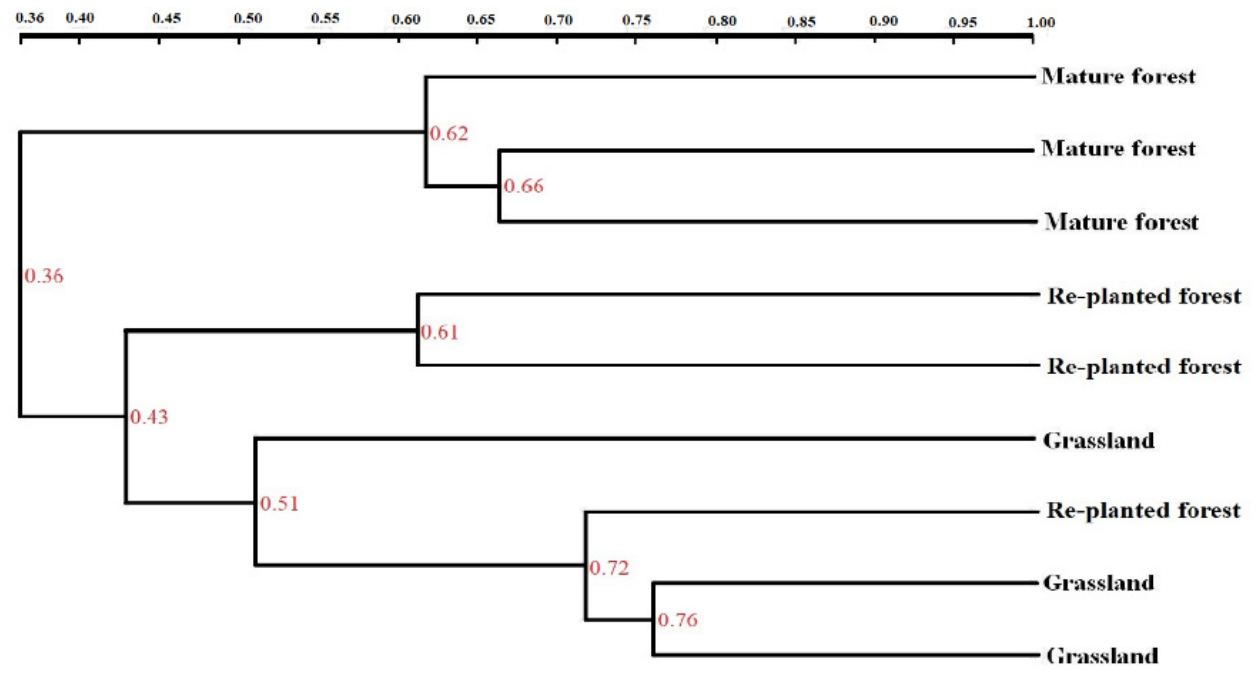

Figure 3. Cluster analysis of soil bacterial community structure under three types of vegetation measured by the unweighted pair group method with arithmetic mean (UPGMA).

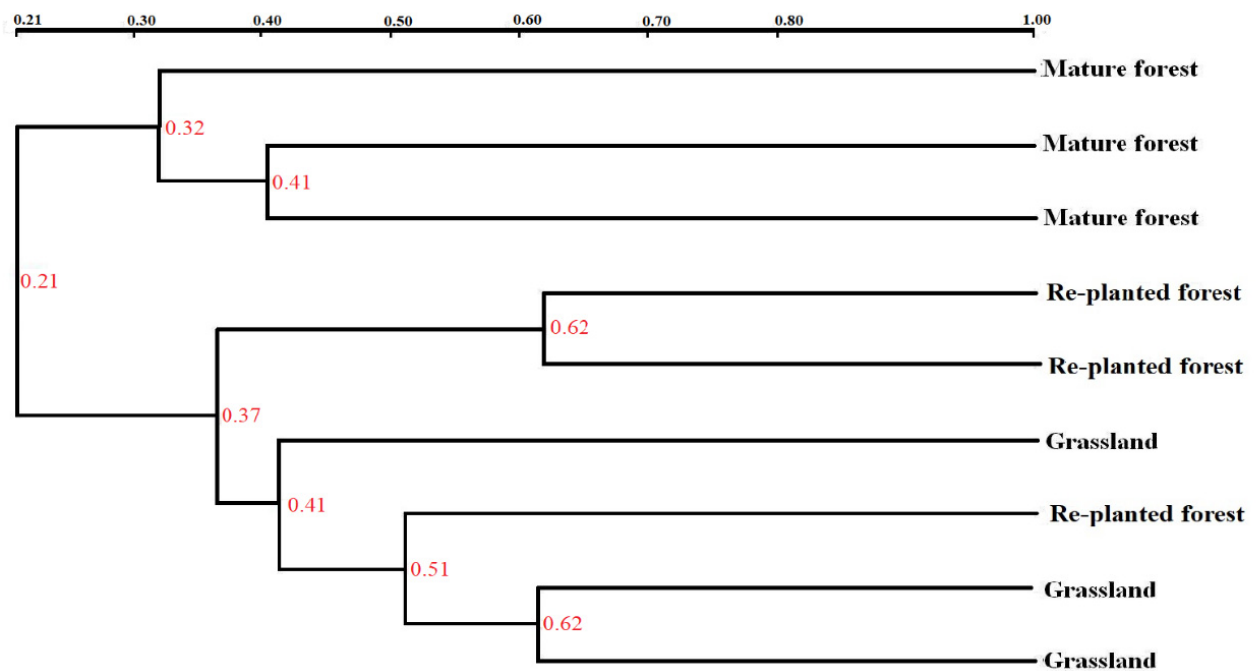

Figure 4. Cluster analysis of fungal community structure in three types of vegetation measured by UPGMA.

\subsection{Correlation of Soil Properties and Microbial Communities}

Soil organic $\mathrm{C}$ was closely correlated with soil levels of enzyme, with the exception of urease and phosphatase, and microbial community composition (Table 4). Total $\mathrm{N}$ content was highly correlated with the organic $\mathrm{C}$ content; the correlation of the total $\mathrm{N}$ content with soil enzymes and microbial community composition not as high as that with organic $C$. $C_{m i c}$ was not correlated with soil enzymes or microbial community composition. Soil $\mathrm{pH}$ was negatively correlated with cellulase and xylanase activity and microbial community composition. 
Table 4. Pearson's correlation coefficients for soil properties, soil enzyme and microbial variables.

\begin{tabular}{|c|c|c|c|c|c|c|c|c|c|c|c|c|}
\hline & Cellulase & Xylanase & Urease & Phosphatase & Total PLFA & Bacteria & $\begin{array}{c}\text { Gram-Positive } \\
\text { Bacteria (G+) }\end{array}$ & $\begin{array}{c}\text { Gram-Negative } \\
\text { Bacteria }(G-)\end{array}$ & $\mathrm{G}+/ \mathrm{G}-$ & Fungi & VAM Fungi & Bacteria/Fungi \\
\hline $\mathrm{C}$ & $0.790^{* * *}$ & $0.849^{* * *}$ & -0.216 & 0.432 & $0.897^{* * *}$ & $0.867^{* * *}$ & $0.876^{* * *}$ & $0.732 * *$ & $0.903 * * *$ & 0.753 ** & $0.776^{* *}$ & 0.517 * \\
\hline $\mathrm{N}$ & 0.569 * & $0.719^{* *}$ & -0.158 & 0.269 & 0.650 ** & 0.564 * & 0.598 * & 0.390 & $0.762 * *$ & $0.633 *$ & 0.505 & $0.529 *$ \\
\hline $\mathrm{P}$ & 0.163 & 0.160 & 0.134 & 0.114 & 0.379 & 0.359 & 0.341 & 0.329 & 0.292 & 0.378 & 0.294 & 0.213 \\
\hline $\mathrm{C} / \mathrm{N}$ & $0.682 * *$ & 0.641 * & -0.178 & 0.426 & $0.710^{* *}$ & $0.796^{* * *}$ & $0.775^{* *}$ & $0.804^{* * *}$ & 0.611 * & 0.398 & $0.733 * *$ & 0.116 \\
\hline $\mathrm{C}_{\text {mic }}$ & 0.485 & 0.362 & 0.166 & 0.319 & 0.486 & 0.409 & 0.399 & 0.309 & 0.394 & $0.657^{* *}$ & 0.279 & 0.511 \\
\hline $\mathrm{N}_{\text {mic }}$ & 0.422 & 0.363 & 0.117 & 0.197 & 0.461 & 0.393 & 0.385 & 0.300 & 0.391 & $0.592 *$ & 0.279 & 0.462 \\
\hline $\mathrm{C}_{\text {mic }} / \mathrm{C}_{\mathrm{org}}$ & -0.587 * & $-0.735^{* *}$ & 0.455 & -0.388 & $-0.844^{* * *}$ & $-0.804^{* * *}$ & $-0.821^{* * * *}$ & $-0.663^{* *}$ & $-0.886^{* * *}$ & -0.627 * & $-0.820^{* * * *}$ & -0.458 \\
\hline $\mathrm{N}_{\text {mic }} / \mathrm{N}_{\text {tot }}$ & $-0.517^{*}$ & $-0.694^{* *}$ & 0.396 & -0.306 & $-0.767^{* *}$ & $-0.701^{* *}$ & $-0.723 * *$ & $-0.543 *$ & $-0.828^{* * *}$ & -0.619 * & $-0.710^{* *}$ & -0.489 \\
\hline $\mathrm{C}_{\text {mic }} / \mathrm{N}_{\text {mic }}$ & 0.368 & 0.196 & 0.312 & 0.083 & 0.289 & 0.251 & 0.239 & 0.203 & 0.181 & 0.451 & 0.062 & 0.311 \\
\hline Moisture & 0.440 & 0.597 * & -0.265 & 0.356 & $0.790^{* * *}$ & $0.683^{* *}$ & $0.696^{* *}$ & 0.487 & $0.805^{* * *}$ & $0.752 * *$ & $0.701^{* *}$ & 0.602 * \\
\hline $\mathrm{pH}$ & $-0.705^{* *}$ & -0.740 ** & 0.041 & -0.201 & $-0.828^{* * *}$ & $-0.845^{* * *}$ & $-0.861^{* * *}$ & -0.769 ** & $-0.825^{* * *}$ & -0.583 * & $-0.751^{* *}$ & -0.336 \\
\hline Cellulose & 1 & $0.886^{* * *}$ & 0.062 & 0.541 * & $0.666^{* *}$ & $0.699 * *$ & $0.683^{* *}$ & 0.679 ** & 0.591 * & 0.580 * & $0.514 *$ & 0.318 \\
\hline Xylanase & $0.886^{* * *}$ & 1 & 0.035 & 0.473 & $0.651 * *$ & $0.676^{* *}$ & $0.683 * *$ & $0.602 *$ & $0.681 * *$ & 0.489 & 0.577 * & 0.265 \\
\hline Urease & 0.062 & 0.035 & 1 & -0.557 * & -0.369 & -0.199 & -0.211 & -0.025 & -0.433 & -0.446 & -0.432 & -0.575 * \\
\hline phosphatase & 0.541 * & 0.473 & $-0.557^{*}$ & 1 & 0.394 & 0.278 & 0.260 & 0.184 & 0.365 & 0.550 * & 0.341 & $0.553 *$ \\
\hline Total PLFA & $0.666^{* *}$ & $0.651^{* *}$ & -0.369 & 0.394 & 1 & $0.959^{* * *}$ & $0.961^{* * *}$ & $0.946^{* * *}$ & $0.936^{* * *}$ & $0.806^{* * *}$ & $0.919^{* * *}$ & $0.556^{*}$ \\
\hline
\end{tabular}




\section{Discussion}

The planting of trees can have direct effects on soil properties [33,34], mostly because of increased soil organic matter (SOM) through the supply of litter and root exudates. In our study of a Pinus plantation in central Taiwan (2600-2800 m asl) after a fire event, the trend we found in soil SOM, total $\mathrm{N}$, microbial activities and microbial community structure may be related to the vegetation and recovery history.

The result of the PCA carried out with soil biochemical parameters clearly indicated a differentiation of chemical properties and soil enzyme activities in soils under different types of vegetation (Figure 1). Soil $\mathrm{pH}$ was more acidic in the mature forest than in the re-planted forest and grassland in our study area, which may be attributed to accumulation of more organic acids under the older forest [35]. We found the soil organic $C$ content increased from the grassland to the mature forest in our study site. SOM is highly correlated with the structure of the microbial community of forest soils because of the quantity and quality of organic matter input [36,37]. Soil microbial biomass is significantly decreased after fire events in coniferous forests $[38,39]$. Furthermore, microbial biomass in forest soils takes decades to recover to the original state once it has been depleted [40]. In our previous study at this site, both levels of microbial biomass $C_{\text {mic }}$ and ratios of fungal to bacterial biomass were higher in the mature forest than the grassland soil [4], but after 15 years of succession at this study site, microbial biomass $\mathrm{C}_{\text {mic }}$ and $\mathrm{N}_{\text {mic }}$ did not differ among the vegetation zones. Our current study suggests that the establishment of a young forest, the Pinus plantation, caused the change in soil $\mathrm{C}_{\text {mic }} / \mathrm{C}_{\text {org }}$ and $\mathrm{N}_{\text {mic }} / \mathrm{N}_{\text {tot }}$ ratios. The soil $\mathrm{C}_{\text {mic }} / \mathrm{C}_{\text {org }}$ ratio may reflect the potential for soil organic mineralization after fresh input of organic materials [41]. The grassland soil in our study site showed the greatest potential for mineralization, with a high $C_{\text {mic }} / C_{\text {org }}$ ratio. Furthermore, the re-planted forest gradually provided more recalcitrant $S O M$ into soil and decreased the $C_{m i c} / C_{\text {org }}$ ratio. The re-planted forest still had a higher $C_{\text {mic }} / C_{\text {org }}$ ratio than the mature forest, which may indicate that the re-planted forest is still under succession.

Recovery of microbial biomass in burned forest-grassland ecosystems is linked to plant community recovery, providing an important interaction between plants and soil microbes [42]. In general, enzyme activities in soil are closely related to the content of organic matter [43] and $\mathrm{C}_{\text {mic }}$ [44]. High SOM usually sustains high $\mathrm{C}_{\text {mic }}$ and enzyme activities [45]. Xylanase is produced and released mostly by fungi in the forest environment [46]. Ali et al. [47] showed that in coniferous tree species such as Pinus taeda L., ectomycorrhizal fungi produce extracellular phosphatase to improve phosphorus uptake. In our study, the mature forest soil had higher fungal biomass than other soils and provided more xylanase and phosphatase (Table 3). In addition, fungal biomass, particularly of vesicular arbuscular mycorrhizal (VAM) fungi, is a good predictor of phosphatase in forest soil [48] which coincides with our results, with high fungal biomass in the mature forest soil (Tables 1 and 3). On the other hand, acid phosphatase activity decreased in soil with severe wildfires [49], which is consistent with our results in the grassland and re-planted forest.

Although soil microbial biomass (both $\mathrm{C}_{\text {mic }}$ and $\mathrm{N}_{\text {mic }}$ ) was similar among the three types of vegetation, urease activity was significantly higher in the grassland than in the re-planted and mature forest. Increased communities of gramineous and herbaceous species of grasses more likely provide higher inputs of labile $\mathrm{C}$ and $\mathrm{N}$ than do perennial forest species. Scott and Binkley [50] showed that the quality of substrate (low lignin to $\mathrm{N}$ ratios) provided by existing plants can directly influence $\mathrm{N}$ turnover rates.

Our PCA of PLFA revealed different microbial communities in soils under different vegetation (Figure 2). Other studies have also shown that associated changes in vegetation rather than direct changes in soil properties may lead to shifts in the soil microbial community structure [51,52].

We found no differences in bacterial biomarker features between grassland and re-planted forest soil. However, fungal and VAM levels were higher in the re-planted forest than the grassland soil. Fungal communities play a dominant role in fresh organic matter decomposition [53]. Djukic et al. [54] showed similar results with higher amounts of fungi in forest soils than in grassland soils. 
Fungal biomass contributes considerably to total biomass in coniferous forest soils [55]. By comparison, high availability of labile substrate (root exudates), for which bacteria are effective competitors, may constrain fungal biomass in grassland sites [54]. Allison et al. [56] found that C inputs in grasslands were mainly derived from root exudates: the rapidly metabolized $\mathrm{C}$ limits the development of fungi because fungi use more recalcitrant sources of $C$.

VAM fungi play an important role in improving plant growth and uptake of nutrients, especially phosphorus [57]. PLFA 16:1 $\omega 5$ is present in VAM fungi [58] and in G- bacteria [59]. Jonasson et al. [60] indicated that $20 \%$ to $30 \%$ of total organic $P$ is immobilized by microbes, and Thoms et al. [61] showed a high association of soil P content and PLFA 16:1w5. The alterations in the 16:1w5 pattern we found support results from previous studies showing higher extractable P in mature forest than other vegetation soils (Table 1 ).

The ratio of fungi to bacteria was increased in the re-planted forest soil (Table 3). The increased ratio of fungi to bacteria can be an important indicator of the amount and composition of litter that enters soils because fungi are the dominant decomposers of plant cell-wall polymers in the litter [62]. In this study, the switch from grassland to forest ecosystems was critical for the source of SOM because these ecosystems differ in the quantity and quality of dead plant biomass input. Although bacterial biomass was similar in the grassland and re-planted forest soils, fungal biomass increases from grassland to re-planted and mature forests. Our previous study found that both soil ergosterol and the respiration rate of fungi to bacteria decreased from the forest to grassland soil [4]. In this study, the ratio of fungi to bacteria PLFA patterns was similar in both the mature forest and re-planted forest soil, which suggests the recovery of the microbial community structure by reforestation after wildfire events.

The composition of the soil microbial community was mainly controlled by the $\mathrm{pH}$ and ratio of $\mathrm{C}$ to $\mathrm{N}$ of the substrate [63]. Bacterial biomass has been reported to increase in soils with a lower $\mathrm{C}$ to $\mathrm{N}$ ratio [64]. Ingham et al. [65] stated that grasslands more strongly dominated by bacteria than a coniferous forest, which supports our results. In grasslands, fast-growing plant species, especially those with highly branched fine root systems, supply large quantities of exudates [66], which are favored by bacteria.

A low ratio of G+/G- bacteria, found in grassland soils, may be due to better growth of Gbacteria under substrate-rich conditions [27]. By contrast, with progressive succession from a grassland to a forest system, the detritus food webs become more complex and recalcitrant. Slow-growing specialists, such as G+ bacteria, are more competitive than $\mathrm{G}-$ bacteria in resource-limited areas [67] because of effective cell metabolism and effective use of recalcitrant substances such as cellulose and lignin in a coniferous environment $[68,69]$. This situation is similar to the decrease in the G+/Gratio for the soils in a bamboo-invaded cedar forest, as herbaceous litter favors the growth of Gbacteria [70].

Our dendrograms of soil bacteria and fungi from PCR-DGGE showed primary differences in the microbial communities related to the succession of vegetation (Figures 3 and 4). By using 16S rRNA gene clone libraries for this same study site, Lin et al. [14] found that the soil bacterial communities differed between the grassland and the mature forest 30 years after the fire. These findings support our results. The Pinus plantation can reform soil microbial communities. Although the microbial community structure was similar in grassland and re-planted forest soil, our DGGE findings agreed with the PCA results of PLFA, showing a distinct composition of bacterial and fungal communities with forest succession.

\section{Conclusions}

Our results suggest substantial changes in microbial community structure with the re-planting of tress in a wildfire-induced grassland. The plantation changed the fraction of the labile form of SOM, with a decrease in the ratio of $\mathrm{C}_{\text {mic }} / \mathrm{C}_{\text {org }}$ in the re-planted forest soil. Microbial biomass (PLFA content) increased from the grassland to the re-planted forest soil, accompanied by increases in fungi and VAM 
fungi but not the bacterial content. The shift in vegetation with the succession of the fire-induced grassland to the forest led to an increased ratio of $\mathrm{G}+/ \mathrm{G}-$ bacteria. DGGE cluster analysis revealed changes in bacterial and fungal community structure associated with the Pinus plantation. Therefore, the planting of trees 30 years ago after a fire in a subalpine area changed the soil microbial activities and community structure, but recovery of the soil microbial community to the original state may need much more time.

Acknowledgments: This work was funded by the Ministry of Science and Technology (MOST-106-2313-B-001-002).

Author Contributions: C.-Y.C. conceived and designed the experiments; E.-H.C. performed the experiments and analyzed the data; E.-H.C. wrote the original draft; G.T. and C.-Y.C. reviewed and edited the manuscript.

Conflicts of Interest: The authors declare no conflict of interest.

\section{References}

1. Smithwick, E.A.H.; Naithani, K.J.; Balser, T.C.; Romme, W.H.; Turner, M.G. Post-fire spatial patterns of soil nitrogen mineralization and microbial abundance. PLoS ONE 2012, 7, e50597. [CrossRef] [PubMed]

2. Pourreza, M.; Hosseini, S.M.; Sinegani, A.A.S.; Matinizadeh, M.; Dick, W.A. Soil microbial activity in response to fire severity in Zagros oak (Quercus brantii Lindl.) forests, Iran, after one year. Geoderma 2014, 213, 95-102. [CrossRef]

3. Dickens, S.J.M.; Allen, E.B. Soil nitrogen cycling is resilient to invasive annuals following restoration of coastal sage scrub. J. Arid Environ. 2014, 110, 12-18. [CrossRef]

4. Imberger, K.T.; Chiu, C.Y. Spatial change of soil fungal and bacterial biomass from a sub-alpine coniferous forest to grassland in a humid, sub-tropical region. Biol. Fertil. Soils 2001, 33, 105-110. [CrossRef]

5. Tavşanoğlu, Ç.; Gürkan, B. Long-term post-fire dynamics of co-occurring woody species in Pinus brutia forests: The role of regeneration mode. Plant Ecol. 2014, 215, 355-365. [CrossRef]

6. Siles, J.A.; Rachid, C.T.C.C.; Sampedro, I.; García-Romera, I.; Tidje, J.M. Microbial diversity of a Mediterranean soil and its changes after biotransformed dry olive residue amendment. PLOS ONE 2014, 9, e103035. [CrossRef] [PubMed]

7. Zhu, X.; Zhu, B. Diversity and abundance of soil fauna as influenced by long-term fertilization in cropland of purple soil, China. Soil Tillage Res. 2015, 146, 39-46. [CrossRef]

8. Bender, S.F.; Heijden, M.G. Soil biota enhance agricultural sustainability by improving crop yield, nutrient uptake and reducing nitrogen leaching losses. J. Appl. Ecol. 2015, 52, 228-239. [CrossRef]

9. Hodge, A.; Storer, K. Arbuscular mycorrhiza and nitrogen: Implications for individual plants through to ecosystems. Plant Soil 2015, 386, 1-19. [CrossRef]

10. Jia, G.M.; Cao, J.; Wang, C.; Wang, G. Microbial biomass and nutrients in soil at the different stages of secondary forest succession in Ziwulin, northwest China. For. Ecol. Manag. 2005, 217, 117-125. [CrossRef]

11. Hedo, J.; Lucas-Borja, M.; Wic, C.; Andrés-Abellán, M.; Las Heras, J.D. Soil microbiological properties and enzymatic activities of long-term post-fire recovery in dry and semiarid Aleppo pine (Pinus halepensis M.) forest stands. Solid Earth 2015, 6, 243-252. [CrossRef]

12. Wang, C.; Wang, G.; Wang, Y.; Rafique, R.; Ma, L.; Hu, L.; Luo, Y. Fire alters vegetation and soil microbial community in alpine meadow. Land Degrad. Dev. 2016, 27, 1379-1390. [CrossRef]

13. Isobe, K.; Otsuka, S.; Sudiana, I.; Nurkanto, A.; Senoo, K. Community composition of soil bacteria nearly a decade after a fire in a tropical rainforest in East Kalimantan, Indonesia. J. Gen. Appl. Microbiol. 2009, 55, 329-337. [CrossRef] [PubMed]

14. Lin, Y.T.; Lin, C.P.; Chaw, S.M.; Whitman, W.B.; Coleman, D.C.; Chiu, C.Y. Bacterial community of very wet and acidic subalpine forest and fire-induced grassland soils. Plant Soil 2010, 332, 417-427. [CrossRef]

15. Frostegård, Å.; Tunlid, A.; Bååth, E. Use and misuse of PLFA measurements in soils. Soil Biol. Biochem. 2011, 43, 1621-1625. [CrossRef]

16. Farrell, M.; Griffith, G.W.; Hobbs, P.J.; Perkins, W.T.; Jones, D.L. Microbial diversity and activity are increased by compost amendment of metal-contaminated soil. FEMS Microbiol. Ecol. 2010, 71, 94-105. [CrossRef] [PubMed] 
17. Matsushita, Y.; Bao, Z.; Kurose, D.; Okada, H.; Takemoto, S.; Sawada, A.; Nagase, H.; Takano, M.; Murakami, H.; Koitabashi, M.; et al. Community structure, diversity, and species dominance of bacteria, fungi, and nematodes from naturally and conventionally farmed soil: A case study on Japanese apple orchards. Org. Agric. 2015, 5, 11-28. [CrossRef]

18. Chiu, C.Y.; Chen, T.H.; Imberger, K.; Tian, G. Particle size fractionation of fungal and bacterial biomass in subalpine grassland and forest soils. Geoderma 2006, 130, 265-271. [CrossRef]

19. McLean, E.O. Soil pH and lime requirement. In Methods of Soil Analysis, Part 2 Chemical and Microbiological Properties; Page, A.L., Ed.; ASA: Madison, WI, USA, 1982; pp. 199-224.

20. Vance, E.D.; Brookes, P.C.; Jenkinson, D.S. An extraction method for measuring soil microbial biomass C. Soil Biol. Biochem. 1987, 19, 703-707. [CrossRef]

21. Wu, J.; Joergensen, R.G.; Pommerening, B.; Chaussod, R.; Brookes, P.C. Measurement of soil microbial biomass C by fumigation-extraction-an automated procedure. Soil Biol. Biochem. 1990, 22, 1167-1169. [CrossRef]

22. Amato, M.; Ladd, J.N. Assay for microbial biomass based on ninhydrin-reactive nitrogen in extracts of fumigated soils. Soil Biol Biochem. 1988, 20, 107-114. [CrossRef]

23. Kandeler, E.; Gerber, H. Short-term assay of soil urease activity using colorimetric determination of ammonium. Biol. Fertil. Soils 1988, 8, 199-202. [CrossRef]

24. Tabatabai, M.A.; Bremner, J.M. Use of $p$-nitrophenyl phosphate for assay of soil phosphatase activity. Soil Biol. Biochem. 1969, 1, 301-307. [CrossRef]

25. Schinner, F.; von Mersi, W. Xylanase-, CM-cellulase- and invertase activity in soil: An improved method. Soil Biol. Biochem. 1990, 22, 511-515. [CrossRef]

26. Frostegård, A.; Tunlid, A.; Baath, E. Phospholipid fatty acid composition, biomass, and activity of microbial communities from two soil types exposed to different heavy metals. Appl. Environ. Microbiol. 1993, 59, 3605-3617. [PubMed]

27. Chang, E.H.; Chen, C.T.; Chen, T.H.; Chiu, C.Y. Soil microbial communities and activities in sand dunes of subtropical coastal forests. Appl. Soil Ecol. 2011, 49, 256-262. [CrossRef]

28. Zogg, G.P.; Zak, D.R.; Ringleberg, D.B.; MacDonald, N.W.; Pregitzer, K.S.; White, D.C. Compositional and functional shifts in microbial communities due to soil warming. Soil Sci. Soc. Am. J. 1997, 61, 475-481. [CrossRef]

29. Zelles, L. Fatty acid patterns of phospholipids and lipopolysaccharides in the characterization of microbial communities in soil: A review. Biol. Fertil. Soils 1999, 29, 111-129. [CrossRef]

30. Nübel, U.; Engelen, B.; Felske, A.; Snaidr, J.; Wieshuber, A.; Amann, R.I.; Ludwig, W.; Backhaus, H. Sequence heterogeneities of genes encoding $16 \mathrm{~S}$ rRNAs in Paenibacillus polymyxa detected by temperature gradient gel electrophoresis. J. Bacteriol. 1996, 178, 5636-5643. [CrossRef] [PubMed]

31. White, T.J.; Bruns, T.; Lee, S.; Taylor, J.W. Amplification and Direct Sequencing of Fungal Ribosomal RNA Genes for Phylogenetics. In PCR Protocols: A Guide to Methods and Applications; Innis, M.A., Gelfand, D.H., Sninsky, J.J., White, J.J., Eds.; Academic Press: New York, NY, USA, 1990; pp. 315-322.

32. Suzuki, C.; Nagaoka, K.; Shimada, A.; Takenaka, M. Bacterial communities are more dependent on soil type than fertilizer type, but the reverse is true for fungal communities. Soil Sci. Plant Nutr. 2009, 55, 80-90. [CrossRef]

33. Umemura, M.; Takenaka, C. Changes in chemical characteristics of surface soils in hinoki cypress (Chamaecyparis obtusa) forests induced by the invasion of exotic Moso bamboo (Phyllostachys pubescens) in central Japan. Plant Species Biol. 2015, 30, 72-79. [CrossRef]

34. Yu, X.; Liu, X.; Zhao, Z.; Liu, J.; Zhang, S. Effect of Monospecific and Mixed Sea-Buckthorn (Hippophae rhamnoides) Plantations on the Structure and Activity of Soil Microbial Communities. PLoS ONE 2015, 10, e0117505. [CrossRef] [PubMed]

35. Chatterjee, A.; Ingram, L.J.; Vance, G.F.; Stahl, P.D. Soil processes and microbial community structures in 45and 135-year-old lodgepole pine stands. Can. J. For. Res. 2009, 39, 2263-2271. [CrossRef]

36. Campbell, C.D.; Cameron, C.M.; Bastias, B.A.; Chen, C.R.; Cairney, J.W.G. Long term repeated burning in a wet sclerophyll forest reduces fungal and bacterial biomass and responses to carbon substrates. Soil Biol. Biochem. 2008, 40, 2246-2252. [CrossRef]

37. Saleem, M. Microbiome Community Ecology: Fundamentals and Applications; Springer International Publishing: New York, NY, USA, 2015. 
38. Hamman, S.T.; Burke, I.C.; Stromberger, M.E. Relationships between microbial community structure and soil environmental conditions in a recently burn system. Soil Biol. Biochem. 2007, 39, 1703-1711. [CrossRef]

39. Hebel, C.L.; Smith, J.E.; Cromack, J.K. Invasive plant species and soil microbial response to wildfire burn severity in the Cascade Range of Oregon. Appl. Soil Ecol. 2009, 42, 150-159. [CrossRef]

40. Malmström, A.; Persson, T.; Ahlström, K.; Gongalsky, K.B.; Bengtsson, J. Dynamics of soil meso- and macrofauna during a 5-year period after clear-cut burning in a boreal forest. Appl. Soil Ecol. 2009, 43, 61-74. [CrossRef]

41. Pascual, J.A.; Hernandez, T.; Ayuso, M.; Garcia, C. Changes in the microbial activity of arid soils amended with urban organic wastes. Biol. Fertil. Soils 1997, 24, 429-434. [CrossRef]

42. Dangi, S.R.; Stahl, P.D.; Pendall, E.; Cleary, M.B.; Buyer, J.S. Recovery of soil microbial community structure after fire in a Sagebrush-grassland ecosystem. Land Degrad. Dev. 2010, 21, 423-432. [CrossRef]

43. Grandy, A.S.; Strickland, M.S.; Lauber, C.L.; Bradford, M.A.; Fierer, N. The influence of microbial communities, management, and soil texture on soil organic matter chemistry. Geoderma 2009, 150, $278-286$. [CrossRef]

44. Mandal, A.; Patra, A.K.; Singh, D.; Swarup, A.; Masto, R.E. Effect of long-term application of manure and fertilizer on biological and biochemical activities in soil during crop development stages. Bioresour. Technol. 2007, 98, 3585-3592. [CrossRef] [PubMed]

45. Chodak, M.; Niklinska, M. The effect of different tree species on the chemical and microbial properties of the reclaimed mine soils. Biol. Fertil. Soils 2010, 46, 555-566. [CrossRef]

46. Dashtban, M.; Schraft, H.; Qin, W. Fungal bioconversion of lignocellulosic residues; Opportunities \& Perspectives. Int. J. Biol. Sci. 2009, 5, 578-595. [PubMed]

47. Ali, M.A.; Louche, J.; Legname, E.; Duchemin, M.; Plassard, C. Pinus pinaster seedlings and their fungal symbionts show high plasticity in phosphorus acquisition in acidic soils. Tree Physiol. 2009, 29, 1587-1597. [CrossRef] [PubMed]

48. Grierson, P.F.; Adams, M.A. Plant species affect acid phosphatase, ergosterol and microbial P in a Jarrah (Eucalyptus marginata Donn ex Sm.) forest in south-western Australia. Soil Biol. Biochem. 2000, 32, 1817-1827. [CrossRef]

49. Vega, J.A.; Fontúrbel, T.; Merino, A.; Fernández, C.; Ferreiro, A.; Jiménez, E. Testing the ability of visual indicators of soil burn severity to reflect changes in soil chemical and microbial properties in pine forests and shrubland. Plant Soil 2013, 369, 73-91. [CrossRef]

50. Scott, N.A.; Binkley, D. Foliage litter quality and annual net N mineralization: Comparison across North American forest sites. Oecologia 1997, 111, 151-159. [CrossRef] [PubMed]

51. Zornoza, R.; Guerrero, C.; Mataix-Solera, J.; Scow, K.M.; Arcenegui, V.; Mataix-Beneyto, J. Changes in soil microbial community structure following the abandonment of agricultural terraces in mountainous areas of Eastern Spain. Appl. Soil Ecol. 2009, 42, 315-323. [CrossRef] [PubMed]

52. Burns, J.H.; Anacker, B.L.; Strauss, S.Y.; Burke, D.J. Soil microbial community variation correlates most strongly with plant species identity, followed by soil chemistry, spatial location and plant genus. AoB Plants 2015, 7, plv030. [CrossRef] [PubMed]

53. Dilly, O.; Bartsch, S.; Rosenbrock, P.; Buscot, F.; Munch, J.C. Shifts in physiological capabilities of the microbiota during the decomposition of leaf litter in a black alder (Alnus glutinosa (Gaertn.) L.) forest. Soil Biol. Biochem. 2001, 33, 921-930. [CrossRef]

54. Djukic, I.; Zehetner, F.; Mentler, A.; Gerzabek, M.H. Microbial community composition and activity in different Alpine vegetation zones. Soil Biol. Biochem. 2010, 42, 155-161. [CrossRef]

55. Smith, S.E.; Read, D.J. Mycorrhizal Symbiosis; Academic Press: San Diego, CA, USA, 1997.

56. Allison, V.J.; Miller, R.M.; Jastrow, J.D.; Matamala, R.; Zak, D.R. Changes in soil microbial community structure in a tallgrass prairie chronosequence. Soil Sci. Soc. Am. J. 2005, 69, 1412-1421. [CrossRef]

57. Parkash, V.; Aggarwal, A.; Sharma, S.; Sharma, D. Effect of endophytic mycorrhizae and fungal bioagent on the development and growth of Eucalyptus saligna seedlings. Bull. Natl. Inst. Ecol. 2005, 15, 127-131.

58. Olsson, P.A.; Baath, E.; Jakobsen, I.; Soderstrom, B. The use of phospholipid and neutral lipid fatty acids to estimate biomass of arbuscular mycorrhizal fungi in soil. Mycol. Res. 1995, 99, 623-629. [CrossRef]

59. Nichols, P.; Stulp, B.K.; Jones, J.G.; White, D.C. Comparison of fatty acid content and DNA homology of the filamentous gliding bacteria Vitreoscilla, Flexibacter, Filibacter. Arch. Microbiol. 1986, 146, 1-6. [CrossRef] 
60. Jonasson, S.; Michelsen, A.; Schmidt, I.K. Coupling of nutrient cycling and C dynamics in the Arctic, integration of soil microbial and plant processes. Appl. Soil Ecol. 1999, 11, 135-146. [CrossRef]

61. Thoms, C.; Gattinger, A.; Jacob, M.; Thomas, F.M.; Gleixner, G. Direct and indirect effects of tree diversity drive soil microbial diversity in temperate deciduous forest. Soil Biol. Boichem. 2010, 42, 1558-1565. [CrossRef]

62. Baldrian, P. Wood-inhabiting ligninolytic basidiomycetes in soils: Ecology and constraints for applicability in bioremediation. Fungal Ecol. 2008, 1, 4-12. [CrossRef]

63. Bååth, E.; Frostegård, A.; Pennanen, T.; Fritze, H. Microbial community structure and pH response in relation to soil organic matter quality in wood-ash fertilized, clear-cut or burned coniferous forest soils. Soil Biol. Biochem. 1995, 27, 229-240. [CrossRef]

64. Sterner, R.W.; Elsner, J.J. Ecological stoichiometry. In The Biology of Elements from Molecules to the Biosphere; Princeton University Press: Princeton, NJ, USA, 2002.

65. Ingham, E.R.; Coleman, D.C.; Moore, J.C. An analysis of food-web structure and function in a shortgrass prairie, a mountain meadow, and a lodgepole pine forest. Biol. Fertil. Soils 1989, 8, 29-37. [CrossRef]

66. Personeni, E.; Loiseau, P. How does the nature of living and dead roots affect the residence time of carbon in the root litter continuum? Plant Soil 2004, 267, 129-141. [CrossRef]

67. Atlas, R.M.; Bartha, R. Microbial Ecology: Fundamentals and Applications; Benjamin/Cummings: Redwood City, CA, USA, 1998.

68. Kourtev, P.S.; Ehrenfeld, J.G.; Haggblom, M. Experimental analysis of the effect of exotic and native plant species on the structure and function of soil microbial communities. Soil Biol. Biochem. 2003, 35, 895-905. [CrossRef]

69. Chang, E.H.; Tian, G.; Chiu, C.Y. Soil microbial communities in natural and managed cloud montane forests. Forests 2017, 8, 33. [CrossRef]

70. Chang, E.H.; Chiu, C.Y. Changes in soil microbial community structure and activity in a cedar plantation invaded by moso bamboo. Appl. Soil Ecol. 2015, 91, 1-7. [CrossRef]

(C) 2017 by the authors. Licensee MDPI, Basel, Switzerland. This article is an open access article distributed under the terms and conditions of the Creative Commons Attribution (CC BY) license (http:/ / creativecommons.org/licenses/by/4.0/). 